\title{
Simulasi Grid Connected PV Dengan Fungsi Kompensasi Daya Reaktif PV-Inverter Menggunakan Kontrol ANN.
}

\author{
Aditya Chandra $\mathrm{H}^{1}$, Euis Ismayati ${ }^{2}$, Syariffudien Zuhrir $^{3}$, Subuh Isnur $\mathrm{H}^{4}$ \\ Jurusan Teknik Elektro - Fakultas Teknik, Universitas Negeri Surabaya, Surabaya, \\ adityahermawan@unesa.ac.id \\ euisismayati@unesa.ac.id \\ zuhrie@unesa.ac.id \\ subuhisnur@unesa.ac.id
}

\begin{abstract}
Abstrak - Implementasi Energi Baru dan Terbarukan (EBT) tenaga surya di Indonesia sudah banyak berkembang. Dari penentuan tarif hingga stabilitas jaringan distribusi, masih banyak kekurangan - kekurangan dari sistim distribusi dengan menggunakan panel surya atau modul PV bila digunakan dalam skema penghasil tenaga listrik atau berperan sebagai Independent Power Producer (IPP)-Residensial. Salah satu kekurangan proses pembangkitan tenaga surya konvensional adalah tidak adanya fungsi kompensasi daya reaktif (Q) karena modul panel surya umumnya digunakan untuk memenuhi keperluan daya aktif $(\mathrm{P})$ baik itu pada jaringan ataupun pada modul beban yang terhubung pada grid utama. Hal ini mengakibatkan rendahnya faktor daya pada beban sehingga sistem harus mengambil kebutuhan daya reaktif dari grid sehingga biaya operasional akan bertambah besar dan mengurangi faktor daya dari jaringan utama. Pada penelitian ini diharapkan dapat memberikan ilustrasi terhadap implementasi sistem PV-Inverter menggunakan kendali Artificial Neural Network (ANN). Injeksi daya aktif dan reaktif pada grid akan diregulasi melalui inverter yang dikendalikan mengunakan ANN dengan referensi daya dari Photovoltaic.
\end{abstract}

Kata Kunci : Photovoltaic, Koreksi faktor daya, ANN.

\begin{abstract}
Implementation of New and Renewable Energy (EBT) solar power in Indonesia has developed a lot. From the pricing of tariffs to the stability of the distribution network, there are still many shortcomings of the distribution system by using Solar Panels or PV modules when used in electricity generating schemes or acting as Residential -Independent Power Producers (IPPs). One of the disadvantages of conventional solar generation is that there is no reactive power compensation function $(Q)$ because solar panel modules are generally used to meet the needs of active power $(P)$ whether on the network or on load modules connected to the main grid. This results in a low power factor on the load so the system must take the reactive power requirements from the grid. These in turn would make the operational costs increase and reduce the power factor of the main network. This research is expected to provide an illustration of the implementation of PV-Inverter systems using the control of Artificial Neural Network (ANN). The active and reactive power injections on the grid will be regulated through controlled inverters using ANN with Photovoltaic reference power.
\end{abstract}

Keywords: Photovoltaic, Power factor correction, ANN.

\section{PENDAHULUAN}

Pembangkitan menggunakan EBT merupakan teknologi yang dapat memecahkan masalah krisis energi yang melanda dunia. Dari data kementerian ESDM dan Direktorat Jenderal Energi Baru dan Terbarukan dan konservasi energi, prospek kebutuhan energi terutama energi fosil sangat besar seiring meningkatnya populasi jiwa di wilayah Indonesia khususnya daerah-daerah dengan perkembangan industri yang besar. Hal ini mengakibatkan kebutuhan energi listrik yang cukup besar dan biaya produksi energi listrik yang besar pula. Ada tiga krisis energi yang pernah terjadi sampai sekarang - krisis minyak 1973, krisis energi 1979, dan kenaikan harga minyak 1990, terlepas dari beberapa krisis regional. Harga telah meningkat dengan cepat selama lima tahun terakhir, berkat permintaan yang terus meningkat dan kekurangan sumber daya energi. Semakin mahalnya energi yang tidak diimbangi 
dengan ketersediaan bahan bakar fosil untuk 20 sampai 50 tahun yang akan datang serta meningkatnya polusi menyebabkan banyak negara yang menggalakkan program hemat energi dan penggunaan energi baru terbarukan termasuk Indonesia. Salah satu metode penghematan energi adalah menggunakan modul pembangkit tenaga listrik surya atau modul photovoltaic yang dihubungkan ke beban dan ke grid. Photovoltaic cell memiliki kemampuan untuk mengkonversikan radiasi energi sinar matahari (photon) menjadi energi listrik DC, tetapi sistem ini tidak dapat memberikan kebutuhan daya untuk beban secara maksimal dikarenakan sistem DC tidak memiliki kemampuan untuk memberikan daya reaktif sehingga tidak dapat memperbaiki faktor daya sisi Grid ataupun pembebanan sendiri. Dengan sistem PV-Inverter dan injeksi daya aktif dan reaktif dapat memenuhi kebutuhan tersebut sehingga beban tidak perlu mengambil daya reaktif dari jaringan sehingga mengurangi faktor daya pada grid. Sistem PV-Inverter juga dapat mereduksi emisi pembakaran bahan bakar fosil, mereduksi investasi pemeliharaan, serta memperbaiki kondisi tegangan pada feeder distribusi [4]. Dalam penelitian ini dibahas jenis pembangkitan EBT pada beban residensial dengan sumber tenaga listrik berupa Photovoltaic (PV) atau Sel Surya yang terintegrasi dengan modul inverter dan converter dengan metoda kontrol sistem Artificial Neural Networks Back-Propagation. Pemasangan Sistem PV pada beban residensial memiliki beberapa keuntungan untuk PLN diantaranya adalah sistem ini dapat me-level (memperbaiki) kurva beban, memperbaiki kondisi tegangan pada feeder, dapat mengurangi tingkat pembebanan pada percabangan dan transformer dari substation, dan dapat mengurangi polusi udara $[2,3]$.

Dalam aplikasinya pengaturan injeksi daya ke jaring distribusi dan beban baik itu reaktif ataupun aktif dilakukan dengan cara mengatur besar tegangan dan fase beda antara fase tegangan grid (PLN) terhadap besar tegangan dan fase dari output tegangan inverter [4,5], Pengaturan aliran daya dari PV menuju inverter diatur dengan terlebih dahulu melalui proses MPPT pada $d c$ to $d c$ converter dan diatur melalui ANN pada kontroler [8,9]. Pengaturan pada [6] dilakukan untuk memberikan keuntungan maksimal dari adanya pembangkitan terbarukan dengan memberdayakan teknik pengontrolan menggunakan Artificial Inteligence untuk mengatur ekstraksi daya dari PV menuju inverter. Perkembangan dari [6] adalah penggunaan ANN sebagai kontroler penyulutan gate dari inverter untuk injeksi daya aktif dan reaktif menuju ke grid sehingga skema kontrol menjadi lebih ringkas dan kerja dari MPPT dan inverter dapat lebih maksimal dan sederhana.

\section{METODE KENDALI PV-INVERTER DENGAN ANN YANG TERHUBUNG KE GRID}

Penelitian ini menggunakan metode kontrol AI berupa ANN yang dapat menggantikan kinerja kedua kontrol MPPT dan Inverter dengan memberikan multiple input dan 3 output berupa sinyal PWM untuk gating boost converter dan sinyal trigger untuk kontrol injeksi daya output yang masuk menuju Grid yang diberikan menuju inverter. Skema keseluruhan dari sistem dapat dilihat pada gambar 1 .

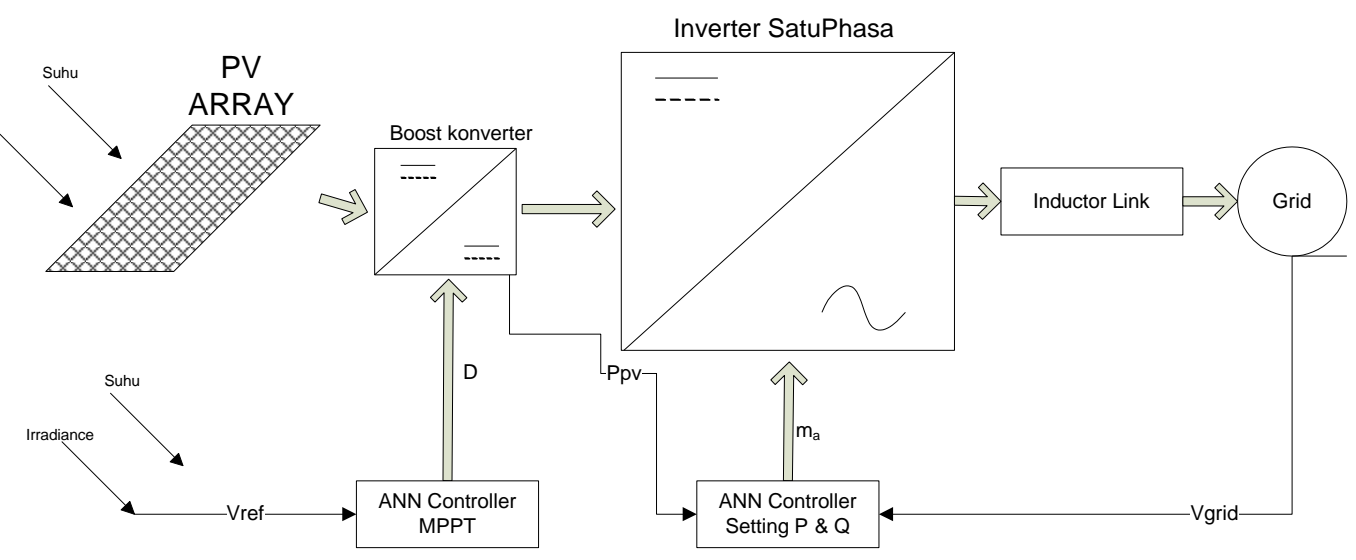

Gambar 1. Skema modul PV [4] 


\section{MODUL PHOTOVOLTAIC}

Sistem menggunakan konfigurasi 16 modul seri. Pengaturan aliran daya dari PV menuju inverter diatur dengan MPPT dan diatur melalui ANN pada kontroler.

Tabel 1 Spesifikasi Modul PV BP-583F dan hasil pengujian simulasi modul PV 1x1. Katalog adalah data pabrik, simulasi adalah data simulasi Simulink dan error adalah persentase kesalahan antara data pabrik dan data simulasi.

\begin{tabular}{cccc}
\hline BP-583F & Katalog & Simulasi & $\begin{array}{c}\text { Error } \\
{[\%]}\end{array}$ \\
\hline $\begin{array}{c}\text { Maksimum power } \\
\text { (Pmax) [W] }\end{array}$ & 75 & 77,56 & 3,30 \\
$\begin{array}{c}\text { Tegangan pada } \\
\text { Pmax [V] }\end{array}$ & 17 & 16,6 & 2,41 \\
$\begin{array}{c}\text { Arus pada Pmax [A] } \\
\quad 4,5\end{array}$ & 4,53 & 0,66 \\
$\begin{array}{c}\text { Open Circuit } \\
\text { Voltage (Voc) [V] }\end{array}$ & 22,3 & 22,3 & 0,00 \\
$\quad$ Short Circuit \\
Current (Isc) [A]
\end{tabular}

Pengaturan pada [6] dilakukan untuk memberikan keuntungan maksimal dari adanya pembangkitan terbarukan dengan memberdayakan teknik pengendalian menggunakan Artificial Inteligence untuk mengatur ekstraksi daya dari PV dan pengaturan penyulutan gate dari inverter untuk injeksi daya aktif dan reaktif sebagai kompensasi factor daya dari sistem dan beban menuju ke grid. Spesifikasi modul PV dan pemodelan yang digunakan pada simulasi ditunjukkan pada tabel 1 dan gambar 1. Pemodelan PV menggunakan data referensi dari rangkaian pengganti PV yang diperlihatkan pada gambar 3. persamaan karakteristik untuk pemodelan solar cell diberikan sebagai berikut $[4,6,9]$ :

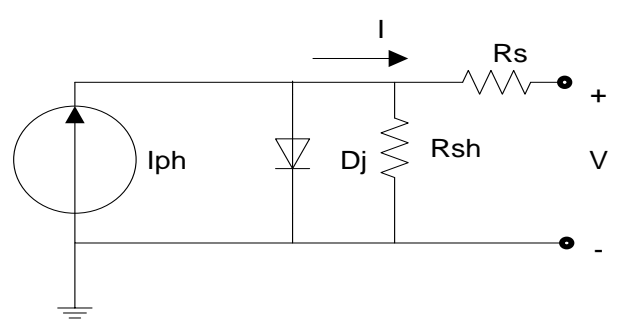

Gambar 3 . Rangkaian pengganti Photovoltaic. [6]

$$
\begin{aligned}
& \mathrm{I}_{\mathrm{o}}=\operatorname{Ior}\left[\frac{\mathrm{T}}{\mathrm{Tr}}\right]^{\beta} \exp \left\lfloor\frac{\mathrm{qE}_{\mathrm{GO}}}{\mathrm{BK}}\left(\frac{1}{\mathrm{~T}_{\mathrm{r}}}-\frac{1}{\mathrm{~T}}\right)\right\rfloor \\
& I p v=I_{s c}-I_{0}\left\lfloor\exp \left(\frac{e(V+I \cdot R s}{\eta k T_{c}}\right)-1\right\rfloor
\end{aligned}
$$

$$
\begin{aligned}
& I^{M}=I^{M}{ }_{s c}\left[1-\exp \left(\frac{V^{m}-V_{o c}^{M}+R_{s}^{M} \cdot I^{M}}{N_{s} \cdot V_{T}^{C}}\right)\right] \\
& I^{M}=N p \cdot I_{s c}^{C}\left[1-\exp \left(\frac{V^{M}-V_{o c}^{C}+R_{s}^{M} \cdot I^{M}}{N_{s} \cdot V_{T}^{C}}\right)\right]
\end{aligned}
$$

Dengan :

$$
\begin{aligned}
& I_{s c}^{C}=\frac{I_{s c 0}^{C}}{G_{a 0}} \cdot G_{a} \\
& V_{o c}^{C}=V_{o c 0}^{C}+0.03 \cdot\left(T_{a}+0.03 \cdot G_{a}-T_{C 0}\right)
\end{aligned}
$$

Perubahan suhu dan irradiasi menghasilkan tegangan dan arus keluaran yang berbeda pada setiap variabel nilai. Perbedaan tersebut menyebabkan perbedaan daya pada setiap nilai suhu dan irradiasi yang berbeda. Perubahan daya ini dapat digunakan untuk mencari karakteristik keluaran dari PV sehingga daerah MPP (maximum power point) dapat diketahui. Data referensi tersebut kemudian digunakan untuk pelatihan ANN. Tujuan dari pelatihan ini adalah untuk mempertahankan ekstraksi daya maksimum yang diberikan menuju PV sehingga ketika ada perubahan irradiasi pada PV modul MPP tetap dapat dipertahankan.

\section{DESAIN INVERTER}

Spesifikasi utama dari inverter yang terhubung pada grid adalah bahwa arus harus diinjeksikan langsung dari panel PV-inverter dengan memperhatikan perubahan pada ekstraksi daya dari photovoltaic (Ppv). Untuk menjelaskan karakteristik dari rangkaian, diperlihatkan diagram phase untuk komponen fundamental dari output tegangan inverter, Vinv, komponen arus output inverter, Iout, induktansi coupling L, dan tegangan induktansi VL, dan komponen fundamental dari tegangan grid utility, Vgrid pada gambar 4 dan gambar 5 [7].

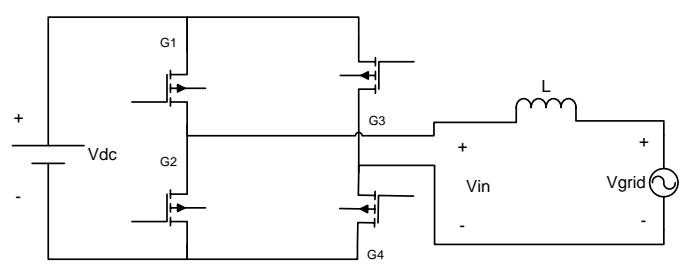

Gambar 4. Rangkaian Inverter phasa 1 [7]. 
Beda phasa antara tegangan grid dan arus fundamental dari output inverter dapat diwakili dengan sudut $(\varphi)$, sedangkan phasa beda (phase shift) antara tegangan grid dan tegangan output dari inverter dapat diwakili dengan sudut $(\delta)$.

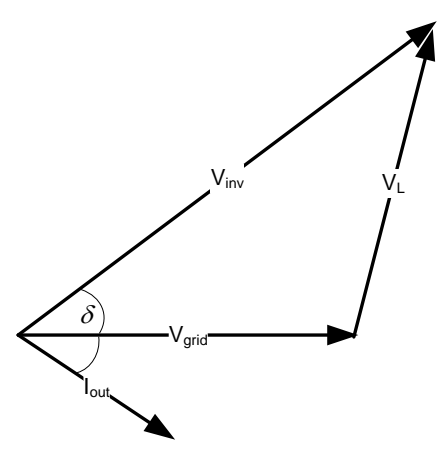

Gambar 5. Diagram fase dengan $V_{i n v}, V_{L}, V_{\text {grid }}$, dan $I_{\text {out }}[4]$

Besarnya arus output inverter, $\mathrm{I}_{\text {out }}$ dan fase inverter, $\varphi$, tergantung pada besarnya tegangan output inverter, $\mathrm{V}_{\mathrm{inv}}$, dan pada fase, $\delta$. Untuk dapat menginjeksikan daya ke grid, kondisi yang perlu diperhatikan adalah nilai dari bus DC output $\mathrm{PV}, \mathrm{V}_{\mathrm{dc}}$, harus cukup tinggi karena tegangan, $\mathrm{V}_{\text {inv }}$, harus memiliki nilai maksimal lebih besar dari atau sama dengan tegangan maksimum grid. $\mathrm{V}_{\text {inv }}$ dapat dinyatakan sebagai fungsi dari indeks modulasi amplitudo, $\mathrm{M}_{\mathrm{a}}$, ketika pola PWM digunakan untuk penyulutan gate inverter. Persamaan. (6) dan (7) menunjukkan hubungan antara $\mathrm{V}_{\mathrm{inv}}, \mathrm{M}_{\mathrm{a}}$ dan tegangan sumber inverter, $\mathrm{V}_{\mathrm{dc}}$.

$V_{i n v}=m_{a} V_{d c}$

$m_{a}=\frac{V_{d c}}{V_{\text {inv }}}$

Dari diagram phase, pada gambar 5, daya aktif dan reaktif secara berurutan ( $\mathrm{P}$ dan $\mathrm{Q}$ ) yang dilalukan dari converter menuju grid dapat diformulasikan dengan persamaan (8) dan (9) [6]. Sehingga daya aktif dan reaktif yang dihasilkan dan yang diserap menuju Grid dapat dikendalikan,

$P=\frac{\text { Vgrid }}{\omega L}($ Vinv $\cdot \sin (\delta))$

$Q=\frac{V g r i d}{\omega L}(\operatorname{Vinv} \cdot \cos (\delta)-\operatorname{Vgrid})$

Sehingga daya aktif dan reaktif yang dihasilkan dan yang diserap menuju grid dapat dikendalikan, dari persamaan (8) dan (9), dapat diambil kesimpulan bahwa nilai dari daya aktif dan reaktif yang mempengaruhi output arus, tergantung dari parameter berikut :

a) Amplitudo dari $\mathrm{V}_{\text {inv }} ; \mathrm{V}$ inverter.

b) Perubahan Fase antara tegangan output Inverter dan Tegangan Grid, $\delta$.

Dari diagram fase, pada Gambar. 3.5b, dapat ditemukan hubungan penting lainnya untuk arus keluaran inverter yang diinjeksikankan pada grid dan pada fasenya dengan persamaan (3) [5].

$I_{\text {out }} \cdot \cos \varphi=\frac{V_{\text {inv }} \cdot \sin \delta}{\omega L}$

Dengan kondisi Tegangan $\mathrm{V}_{\mathrm{L}}$ :

$\left|V_{L}\right|=\omega . L . I_{\text {out }}$

Besarnya arus output inverter, Iout dan fase inverter, $\varphi$, tergantung pada besarnya tegangan output inverter, $\mathrm{V}_{\text {inv }}$, dan pada fase, $\delta$. Untuk dapat menginjeksikan daya ke grid, kondisi yang perlu diperhatikan adalah nilai dari bus DC output $\mathrm{PV}, \mathrm{V}_{\mathrm{dc}}$, harus cukup tinggi karena tegangan, $V_{\text {inv }}$, harus memiliki nilai maksimal lebih besar dari atau sama dengan tegangan maksimum grid. Pada penilitian ini, diasumsikan bahwa pada saat daya reaktif disuntikkan ke dalam grid kondisi harmonik sangat rendah $(\mathrm{THD} \approx 0)$. Faktor daya, $\mathrm{PF}$ ditentukan, oleh $\cos \varphi$ yang diasumsikan mendekati unity yang dideduksi dari Persamaan (10). Daya inverter dapat dikontrol dengan mengubah perbedaan phasa $\delta=\delta_{V}-\delta_{E}$ antara inverter dengan tegangan grid yang diatur dengan cara mengontrol modulasi penyulutan inverter yang dapat dilakukan dengan membandingkan input referensi daya dari photovoltaic dan beda phasa antara arus inverter dan tegangan grid. Lalu referensi tersebut digunakan untuk setting modulasi inverter sehingga daya aktif dan reaktif dari sistem PV dapat ditentukan sesuai dengan daya maksimum yang diberikan oleh Photovoltaic.

\section{DESAIN KENDALI NEURAL NETWORKS}

Data pelatihan untuk setiap perubahan $\mathrm{P}$ dan $\mathrm{Q}$ pada Grid terhadap perubahan daya pada input DC/DC konverter sebagai MPPT dan juga dari tegangan dan arus serta perbedaan phase dari grid dapat diketahui. 


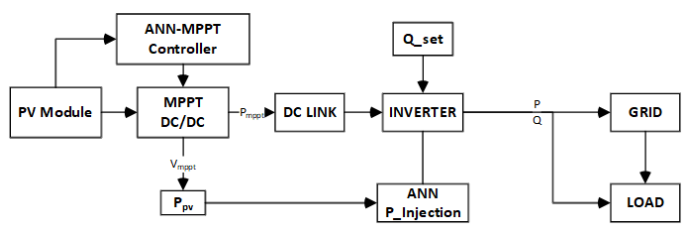

Gambar 6. Skema sistem PV-Inverter dan kompensasi daya reaktif

Kemudian data tersebut dibuat menjadi tabel perubahan data dari $\mathrm{V}_{\text {grid }}, \mathrm{I}_{\mathrm{Inv}}, \mathrm{V}_{\mathrm{pv}}$ dan $\mathrm{I}_{\mathrm{pv}}$ serta Phase Shift antara phase tegangan Grid dan tegangan Inverter diketahui dari PLL atau ZCD. Data ini digunakan untuk data pelatihan input ANN sehingga kendali yang dapat mendekati respons yang diinginkan dapat dicapai. Pelatihan dari ANN controller sisi MPPT dilakukan dengan cara mengambil data tegangan pada saat daya maksimum sebagai target, dengan data irradiance dan suhu sebagai input masukan dari PV. Data tersebut kemudian digunakan untuk mendapatkan data pelatihan ANN yang dapat memaksimalkan daya output dari keluaran PV sehingga MPP dipertahankan meskipun terjadi perubahan mendadak terhadap irradiasi. Skema pelatihan ANN - MPPT dapat dilihat pada gambar 7 dengan 2 input masukan dan 1 output keluaran, memiliki 20 hidden layer dengan MSE (Mean Squared Error) kurang dari 0,36728 .

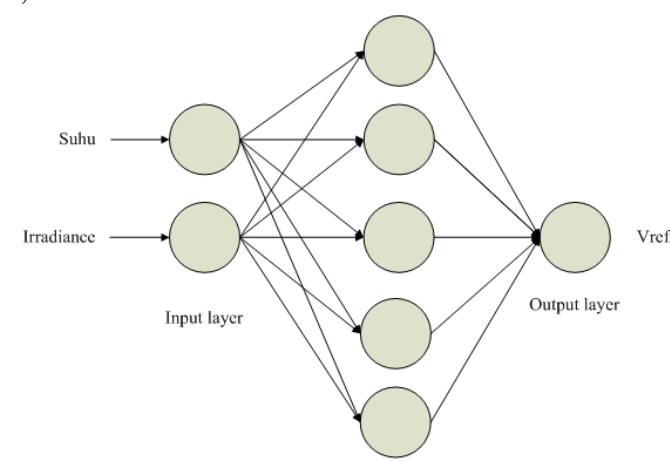

Gambar 7 [4]. Pelatihan MPPT Boost Konverter.

Pelatihan dari ANN controller sisi Inverter dilakukan dengan cara mengambil data perbandingan sinyal grid dengan data modulasi inverter $\mathrm{m}_{\mathrm{a}}$ sebagai target, dengan data daya aktif MPPT serta referensi daya reaktif sebagai input masukan dari PV. Data tersebut kemudian digunakan untuk mendapatkan data pelatihan ANN yang dapat memaksimalkan daya output dari keluaran Inverter sehingga MPP dipertahankan meskipun terjadi perubahan terhadap irradiasi pada PV sehingga kinerja
MPP dari sisi modul MPPT dapat dipertahankan sekaligus daya yang disalurkan menuju grid dapat lebih maksimum. Skema pelatihan ANN Sistem dapat dilihat pada gambar 8 dengan 2 input masukan dan 2 output keluaran, memiliki 20 hidden layer dengan MSE kurang dari $0,36728[8]$.

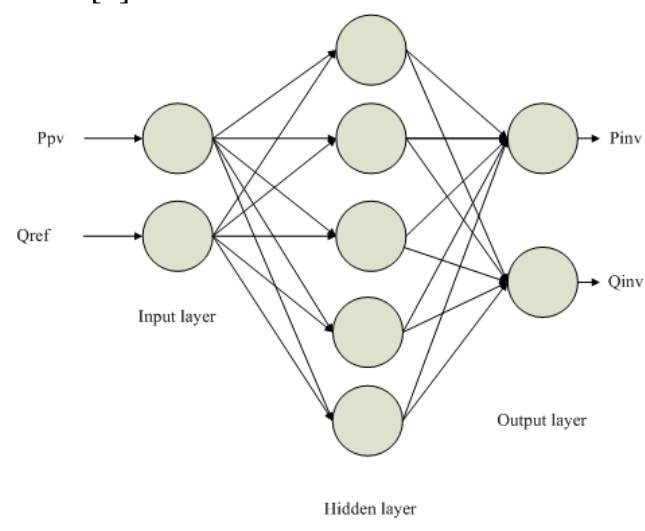

Gambar 8 [4]. Pelatihan MPPT Boost Konverter.

\section{KONSEP KOMPENSASI DAYA REAKTIF}

Pada umumnya beban industri dan residen yang digunakan memiliki faktor daya minimum sebesar $85 \%$. Dari distribusi beban, arus tertinggal terhadap tegangan sehingga kondisi faktor daya (pf) tertinggal. Cosinus antara arus dan tegangan sisi kirim dikenal sebagai faktor daya. Jika arus sisi grid dan arus sisi beban masing-masing dikalikan dengan tegangan sisi kirim dan tegangan sisi terima, akan didapat hubungan segi tiga daya seperti gambar 9 yang menunjukkan hubungan segi-tiga antara kilo Watt, kilo Volt Ampere dan kilo Volt Ampere Reaktif. Daya aktif (P) merupakan daya effektif yang disalurkan dari sisi grid menuju beban, sedangkan daya reaktif (Q) merupakan daya yang diserap oleh beban ketika beban tersebut bersifat induktif. Beban induktif menyebabkan sinyal arus tertinggal phasa terhadap tegangan (lagging) sehingga faktor daya $(\cos \theta)$ menjadi kurang dari 1[2]. Standar PUIL 2011[5] menyebutkan parameter minimum faktor daya dari PLN untuk industri dan beban besar harus lebih dari 0,85 . Dengan data tersebut dengan memperhitungkan faktor daya kompensasi Q dan perbandingannya dengan $\mathrm{P}$ kita dapat menyimpulkan bahwa :

$$
Q_{\text {Grid }}=0,62 P_{\text {Load }}
$$


Dimana $\mathrm{Q}_{\text {Grid }}$ adalah daya reaktif yang diserap oleh beban dari jaring PLN sedangkan $\mathrm{P}_{\text {Load }}$ adalah daya aktif yang diserap oleh beban. Dengan grid mensuplai beban maka faktor daya Grid $(\cos \theta)$ akan semakin rendah (Gambar 9a) karena :

$$
\begin{aligned}
& \cos \theta=\frac{P}{S} \\
& \tan \theta=\frac{Q}{P}
\end{aligned}
$$

Untuk mengatasi hal ini diperlukan kompensasi daya reaktif oleh modul PV-Inverter dengan menginjeksikan daya reaktif ke beban sehingga Q yang diserap oleh beban dari grid akan berkurang (Gambar 9b).

$$
Q_{\text {com }}=Q_{\text {Grid }}-Q_{p v}
$$

Dengan memperhatikan persamaan (12) maka :

$$
Q_{\text {com }}=P\left[\tan \theta_{1}-\tan \theta_{2}\right]
$$

Dari persamaan (13) dan (16) dapat disimpulkan bahwa proses injeksi daya reaktif ke beban juga memperbaiki faktor daya pada grid karena sudut $\alpha=\theta$ akan semakin kecil sehingga nilai $\cos \theta$ akan semakin mendekati 1 (unity) [1,2].

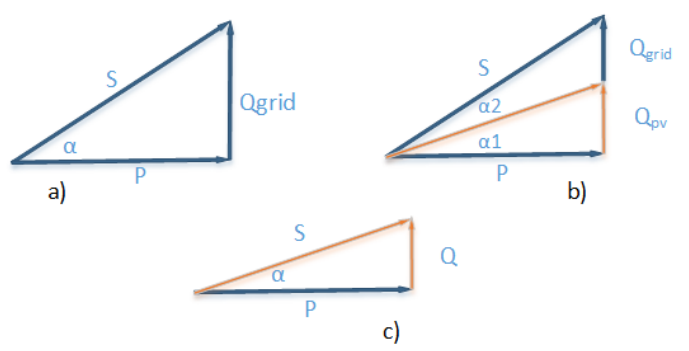

Gambar 9. Ilustrasi segitiga daya dan kompensasi daya reaktif.

\section{SIMULASI KOMPENSASI DAYA DAN FAKTOR DAYA.}

Dari tabel 1 dapat dilihat performansi dari modul BP-583F, antara data katalog terhadap hasil simulasi simulink dengan menggunakan MatLAB. Terdapat perbedaan yang relatif kecil dengan error yang kecil pula. Perubahan suhu dan irradiasi menghasilkan tegangan dan arus keluaran yang berbeda pada setiap variabel nilai. Perbedaan tersebut menyebabkan perbedaan daya pada setiap nilai suhu dan irradiasi yang berbeda. Dari gambar 4.2a. dapat dilihat grafik fungsi arus terhadap tegangan PV pada suhu $25{ }^{\circ} \mathrm{C}$ untuk variasi irradiasi 1000 $\mathrm{W} / \mathrm{m}^{2}, 900 \mathrm{~W} / \mathrm{m}^{2}$, dan $800 \mathrm{~W} / \mathrm{m}^{2}$.

Tabel 2. Performansi kinerja MPPT serta nilai kesalahan tegangan sistem kendali terhadap tegangan aktual $\mathrm{P}_{\mathrm{pv}}[4]$

\begin{tabular}{lllll}
\hline $\begin{array}{l}\text { Irradiasi } \\
(\mathbf{k W} / \mathbf{m} 2)\end{array}$ & Suhu $\left({ }^{\circ} \mathbf{C}\right)$ & Vop $(\mathbf{V})$ & $\begin{array}{l}\text { Vout_Boost } \\
(\mathbf{V})\end{array}$ & Error \\
\hline 1 & 25 & 276 & 276,31 & 0,11 \\
0.9 & 25 & 271 & 271,40 & 0,15 \\
0.8 & 25 & 270 & 269,59 & 0,15 \\
0.7 & 25 & 270 & 268,65 & 0,50 \\
0.6 & 25 & 266 & 265,75 & 0,09 \\
0.5 & 25 & 262 & 261,98 & 0,01 \\
0.4 & 25 & 258 & 256,87 & 0,44 \\
0.3 & 25 & 252 & 250,65 & 0,53 \\
0.2 & 25 & 242 & 241,03 & 0,40 \\
0.1 & 25 & 224 & 223,65 & 0,16 \\
0 & 25 & 0 & 0,1 & 0.22 \\
\hline
\end{tabular}

Performa dari kinerja MPPT dengan ANN dapat dilihat pada tabel 2 dimana PV beroperasi pada suhu $25^{\circ} \mathbf{C}$ dengan irradiasi yang bervariasi dari 0 sampai $1000 \mathrm{~W} / \mathrm{m}^{2}$. Data pada tabel 2 menunjukkan error perbedaan tegangan kerja boost dan tegangan kerja Vop yang dibutuhkan untuk mencapai kinerja maksimal memenuhi nilai daya Pmax pada suhu $25^{\circ} \mathbf{C}$.

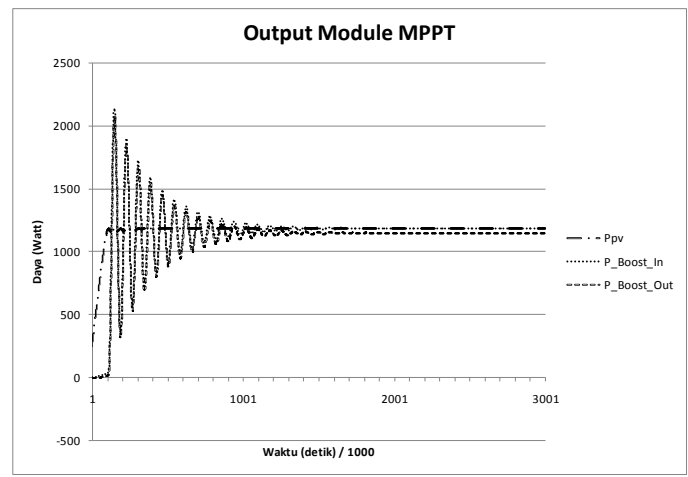

Gambar 10. Perbandingan output daya dari Boost Konverter terhadap daya dari modul Photovoltaic.

Gambar 10 menggambarkan besar daya yang keluar dari boost konverter. Besar daya diambil dari arus rata-rata dikalikan dengan tegangan rata-rata. $\mathrm{P}_{\mathrm{pv}}$ adalah daya yang dihasilkan oleh modul photovolatic, sedangkan P_Boost_In adalah daya yang masuk menuju Boost converter. Sedangkan P_Boost_Out adalah daya yang keluar dari Boost converter menuju Inverter.

Tabel 3 Efisiensi sistem MPPT dengan suhu $35{ }^{\circ} \mathrm{C}$ dan variasi irradiasi dari $1000 \mathrm{~W} / \mathrm{m}^{2}$ hingga $600 \mathrm{~W} / \mathrm{m}^{2}$. 


\begin{tabular}{llllll}
\hline No. & $\begin{array}{l}\text { Suhu } \\
\left({ }^{\circ} \mathbf{C}\right)\end{array}$ & $\begin{array}{l}\text { Irradiasi } \\
(\mathbf{W} / \mathbf{m} 2)\end{array}$ & Ppv (W) & $\begin{array}{l}\text { Pmax } \\
(\mathbf{W})\end{array}$ & $\begin{array}{l}\text { Eff } \\
(\%)\end{array}$ \\
\hline 1 & 35 & 1000 & 1180,3 & 1145,8 & 97,08 \\
2 & 35 & 800 & 930,27 & 895,27 & 96,24 \\
3 & 35 & 600 & 681,86 & 646,02 & 94,74 \\
\hline
\end{tabular}

Hasil simulasi dengan MPPT menunjukkan daya yang disalurkan oleh panel surya $\left(\mathrm{P}_{\mathrm{pv}}\right)$ dengan irradiasi $1000 \mathrm{Watt} / \mathrm{m}^{2}$ dan suhu $35{ }^{\circ} \mathrm{C}$ adalah 1180,3 Watt sedangkan daya yang menuju boost converter setelah melewati kapasitor adalah 1180,29 Watt. Daya yang disalurkan menuju Inverter dari modul boost converter adalah 1145,81 Watt, ini menunjukkan effisiensi kerja dari boost converter dengan daya input dan output menuju grid sebesar 97,08 \%, hal ini membuktikan bahwa kinerja dari sistem ANN - MPPT memiliki rating efisiensi yang sangat baik. Lamanya boost konverter mencapai steady state bergantung pada besar Induktor yang dipakai pada boost converter. Dapat dilihat bahwa output daya dari sistem hampir sama dengan output daya dari PV, hal ini membuktikan kinerja dari sistem inverter sangat efisien yang dapat dilihat pada tabel 3 .

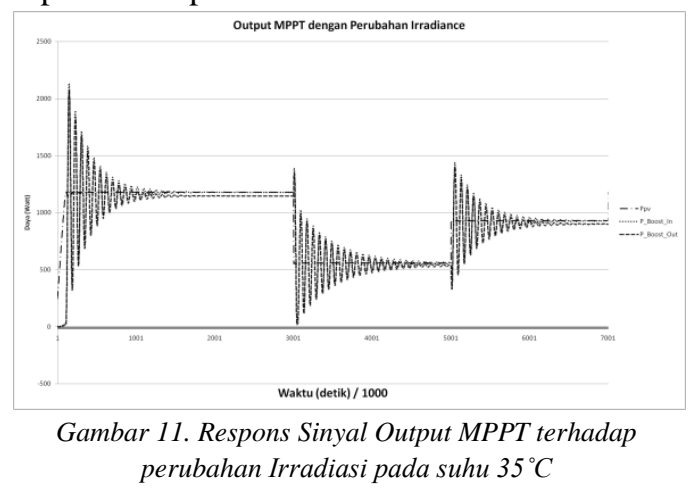

Pada gambar 11 menunjukkan saat irradiance maksimum $1000 \mathrm{~W} / \mathrm{m}^{2}$ dan suhu dijaga tetap 35 ${ }^{\circ} \mathrm{C}$ dengan daya aktif dari Boost Converter sebesar 1168,48 Watt serta daya reaktif set sebesar 100 VAR, output daya dari sistem menunjukkan 1168,192 Watt untuk daya aktif dan 100,158 VAR untuk daya reaktif, dengan ini didapatkan akurasi kedekatan nilai referensi dengan nilai output sistem dengan kendali regualasi ANN sebesar 99,97\% untuk daya aktif dan 99,84\% untuk daya reaktif. Hal ini membuktikan rating kerja sistem Inverter yang tinggi. Hal ini untuk menguji effisiensi dari Inverter seperti terlihat pada tabel 4. Pengujian kualitas kendali ANN pada Inverter juga dapat ditentukan dengan cara melihat akurasi dari daya yang disalurkan menuju Grid.

Tabel 4 Kinerja PV - Inverter sistem dengan irradiance variabel dari $1000 \mathrm{~W} / \mathrm{m}^{2}$ sampai $200 \mathrm{~W} / \mathrm{m}^{2}$ dengan suhu dijaga pada $35^{\circ} \mathbf{C}[4]$

\begin{tabular}{|c|c|c|c|c|c|c|}
\hline & Irrd & Suhu & $\begin{array}{c}\text { Luas } \\
\text { PV }\end{array}$ & Psun & Ppv & Pboost \\
\hline No. & $(\mathrm{W} / \mathrm{m} 2)$ & $\left({ }^{\circ} \mathrm{C}\right)$ & (m2) & (W) & (W) & (W) \\
\hline 1. & 1000 & 35 & 9072 & 9072 & 1180,28 & 1168,48 \\
\hline 2. & 800 & 35 & 9072 & 7257,6 & 930,27 & 911,97 \\
\hline 3. & 600 & 35 & 9072 & 5443,2 & 681,86 & 668,27 \\
\hline 4. & 400 & 35 & 9072 & 3628,8 & 437,56 & 428,82 \\
\hline \multirow[t]{2}{*}{5.} & 200 & 35 & 9072 & 1814,4 & 202,55 & 198,48 \\
\hline & Irrd & Suhu & $\begin{array}{c}\text { Eff } \\
\text { boost }\end{array}$ & Eff & Eff. Inverter & Eff. Sistem \\
\hline No. & $(\mathrm{W} / \mathrm{m} 2)$ & $\left({ }^{\circ} \mathrm{C}\right)$ & $(\%)$ & PV & $(\%)$ & $(\%)$ \\
\hline 1. & 1000 & 35 & $\begin{array}{c}99 \\
98,0\end{array}$ & 13,01 & 99,98 & 12,75 \\
\hline 2. & 800 & 35 & $\begin{array}{c}3 \\
98,0\end{array}$ & 12,82 & 99,91 & 12,44 \\
\hline 3. & 600 & 35 & 1 & 12,53 & 99,80 & 12,15 \\
\hline 4. & 400 & 35 & $\begin{array}{c}98 \\
97,9\end{array}$ & 12,06 & 99,83 & 11,7 \\
\hline 5. & 200 & 35 & 9 & 11,16 & 99,93 & 10,83 \\
\hline
\end{tabular}

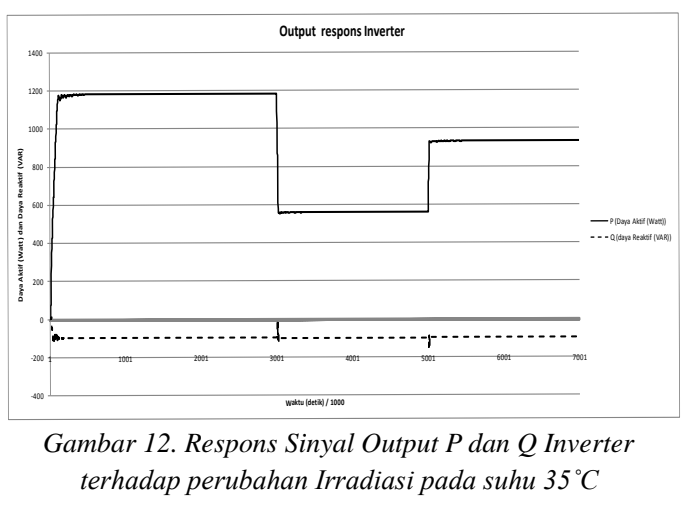

Dari tabel 4 dan tabel 5 dan gambar 12 dapat dilihat dampak perubahan irradiasi pada sisi PV terhadap daya output dari Inverter.

Tabel 5 Kompensasi Daya Reaktif serta perubahan faktor daya terhadap pembebanan.

\begin{tabular}{rlcccr}
\hline No. & $\begin{array}{l}\text { PInv } \\
\text { (W) }\end{array}$ & $\begin{array}{l}\text { Qinv } \\
\text { (VAR) }\end{array}$ & $\begin{array}{l}\text { Pload } \\
\text { (W) }\end{array}$ & $\begin{array}{l}\text { Qload } \\
\text { (W) }\end{array}$ & $\begin{array}{r}\text { PF } \\
\text { Load }\end{array}$ \\
\hline 1 & 1145,8 & 100,16 & 1110,0 & 1900 & 0,93 \\
\hline 2 & 895,27 & 100,16 & 1222,2 & 1800 & 0,7 \\
\hline 3 & 646,02 & 100,16 & 1952,0 & 1000 & 0,64 \\
\hline
\end{tabular}

Irradiasi $1000 \mathrm{~W} / \mathrm{m}^{2}$ (tabel 3 no. 1) daya dari PV sebesar 1180,3 output boost menunjukkan 1145,73 Watt, pf 0,64 dengan output sistem PVInverter 1142,6 Watt. Ketika terjadi penurunan irradiasi dari $1000 \mathrm{~W} / \mathrm{m}^{2}$ menjadi $500 \mathrm{~W} / \mathrm{m}^{2}$ 
pada detik ke - 3 maka sistem kendali ANN merespon dengan menurunkan output boost sehingga daya tetap terjaga pada daya maksimumnya sebesar 646,2 Watt dan pf 0,64. Dalam jangka waktu tersebut kendali inverter merespon dengan membaca output $\mathrm{P}_{\mathrm{pv}}$ sehingga sistem cepat men-setting data menjadi 650 Watt dengan daya reaktif tetap pada $Q=100,083$ VAR. Setelah detik ke -5 irradiance kembali naik menjadi $900 \mathrm{~W} / \mathrm{m}^{2}$ dengan output sistem MPPT menjadi 895,27 watt sedangkan respon daya pada inverter 895 , watt, dan pf 0,7 hal ini menunjukkan tingkat keandalan sistem dengan waktu respon perubahan output boost converter kurang dari 0.029 detik dengan waktu respon terhadap perubahan daya PV kurang dari 0,023 detik. Perubahan pembebanan daya aktif disini di bantu dengan daya yang disalurkan oleh grid, sedangkan daya reaktif maksimum yang dapat disalurkan dari modul pv-inverter sebesar 100,083 VAR. Dari 3 iterasi data pada tabel 5 didapatkan faktor daya terbaik sebesar 0,93 dengan pembebanan 646,02 Watt.

\section{PENUTUP}

\section{Simpulan}

Dari hasil percobaan diketahui bahwa Sistem PV memiliki daya optimal pada irradiasi 1000 $\mathrm{W} / \mathrm{m} 2$ dan suhu $35^{\circ} \mathrm{C} \mathrm{PV}$ sebesar $1.24 \mathrm{~kW}$. Dengan menggunakan kendali ANN pada sisi MPPT, MSE (margin error) didapatkan sebesar 0,0036728 dengan tingkat akurasi output rata rata 96,63\% sedangkan sisi Inverter memiliki MSE sebesar 0,000461 dengan tingkat akurasi output rata - rata 96,40\%. Sistem PV-Inverter memiliki akurasi output daya yang tinggi mencapai 99,97\% untuk output daya 1168,192 Watt dengan akurasi daya reaktif mencapai 99 $\%$ hal ini memberikan gambaran jelas tentang plausability dari skema rancang modul PVInverter sebagai sumber daya Aktif dan Reaktif. Kompensasi daya dari sistem memiliki batasan maksimum daya reaktif (Q) sebesar 100,16 VAR.

\section{Saran}

Dengan batasan tertentu, kompensasi ini dapat membantu memperbaiki faktor daya beban mencapai 0,93 serta mengurangi kebutuhan daya rekatif yang diserap melalui grid PLN. Tetapi desain PV-Inverter memiliki kelemahan dimana besar daya reaktif maksimum sebesar 100,16 VAR untuk kapasitas daya aktif maksimum 1145 Watt, hal ini juga dibatasi dengan kinerja MPPT yang dipengaruhi oleh irradiasi surya. Untuk mengatasi hal - hal tersebut dibutuhkan modul PV yang di seri lebih banyak, penambahan DC link dan modul penyimpanan energi seperti baterei serta perangkat pendukung dengan kapasitas daya yang lebih besar.

\section{Pustaka}

[1] Liudvinavičius, Lionginas. "The Methods Of Reactive Power Compensation In The $25 \mathrm{kV}, 50 \mathrm{~Hz}$ Contact Network".

[2] Fazal $\mathbf{M}^{*}$, Waleed Raza $\mathrm{M}$, Khan S, Faizullah. "Reactive Power Compensation by Power Capacitor Method". Open Access Journal Engineering Technology, Juniper Publisher, 2018.

[3] Kementerian Energi dan Sumber Daya Mineral, Dirjen Ketenagalistrikan. "Statistik Ketenagalistrikan 2017", Edisi no. 31, 2018.

[4] Hermawan, Aditya. C. "Desain Sistem Inverter - PV Menggunakan Artificial Neural Networks Untuk Injeksi Daya Aktif Dan Reaktif', Electrical Engineering, RTE 621.312 44 Her d, 2013.

[5] Tim HIMAPUIL. "Persyaratan Umum Instalasi Listrik 2011”. PLN, Indonesia, 2011.

[6] L. Hassaine, E. Olias, J.quintero, M. Haddadi, "Digital power factor control and reactive power regulation for grid connected photovoltaic inverter", Renewable Energy, Elsevier. 2008.

[7] Muhammad H. Rashid, "Power Electronics Handbook", Academic Press, ISBN : 0-12-581650-2, London NW1 7BY, UK

[8] Mauridhi Hery Purnomo, "Supervised Neural Networks dan Aplikasinya”, Graha Ilmu, ISBN-13: 978-979-756-123-9, Yogyakarta, 2006.

[9] S. Premrudeepreechacharn, N. Patanapirom. "Solar-Array Modelling and Maximum Power Point Tracking Using Neural Networks", Bologna Power Tech Conference 23th - 26th, Bologna, Italy. IEEE, 2003 